\title{
Sprawozdanie z III Zimowego Forum Onkologicznego w Zakopanem
}

Już po raz trzeci 24 stycznia 2015 r. w Zakopanem odbyło się Zimowe Forum Onkologiczne, które obejmowało III Zimową Konferencję Szkoleniową PTChO oraz III Otwarte Zawody Narciarskie o Puchar PTChO.

Sesja naukowa została otwarta przez Prezesa PTChO prof. Piotra Rutkowskiego oraz prof. Andrzeja Stelmacha. W pierwszej kolejności prof. Krzysztof Herman (konsultant krajowy w dziedzinie chirurgii onkologicznej) zaprosił uczestników do otwartej dyskusji na temat wdrażanych obecnie zmian w organizacji systemu ochrony zdrowia („pakietu onkologicznego”). Na specjalne zaproszenie w plenarnej debacie wzięli również udział: prof. Piotr Rutkowski, prof. Jerzy Jakubowicz (Dyrektor Centrum Onkologii — Instytutu im. Marii Skłodowskiej-Curie, Oddziału w Krakowie), dr Zbigniew Darasz (Z-ca Dyrektora Centrum Onkologii — Instytutu im. Marii Skłodowskiej-Curie Oddziału w Krakowie), dr Michał Jankowski (Bydgoskie Centrum Onkologii). Podczas dyskusji starano się wypunktować wiele niejasności zawartych w nowo wprowadzonych zmianach oraz problemów w finansowaniu leczenia pacjentów onkologicznych. Ta część spotkania swoją formą odbiegała od typowego charakteru konferencji, co nadało jej interaktywny charakter, który pobudzał uczestników do aktywnego udziału w rozmowie i dzieleniu się swoimi spostrzeżeniami i problemami we wprowadzaniu pakietu w swoich jednostkach.

Następnie wykład wygłosił prof. Jarosław Kużdżał. Dotyczył on współczesnej roli chirurgii w leczeniu chorych na lokoregionalnie zaawansowanego raka płuca. Szczególnie cenne były zalecenia dotyczące postępowania z przypadkami granicznymi tego nowotworu. Kolejne, bardzo ciekawe wystąpienia dr Emilii Filipczyk-Cisarż, dr Aleksandry Greli-Wojewody oraz dr. Marcina Kowalskiego dotyczyły elementów leczenia systemowego chorych na raka płuca, raka piersi i raka żołądka. Z kolei anestezjolog dr Łukasz Nowak przedstawił temat, jak efektywnie leczyć przeciwbólowo chorych na zaawansowane nowotwory złośliwe.

W Konferencji uczestniczyło łącznie około 50 osób z różnych stron kraju, reprezentujących wszystkie specjalizacje medyczne związane z leczeniem onkologicznym.

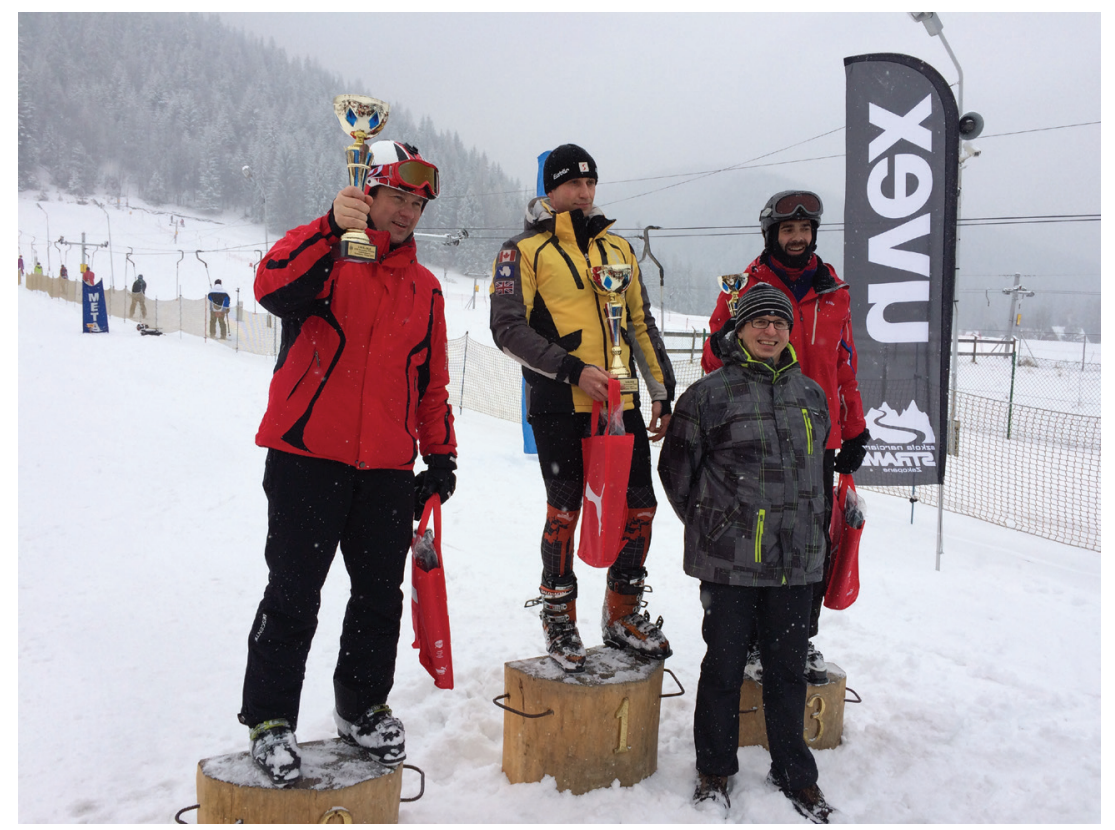

Prezes PTChO prof. Piotr Rutkowski i czołówka zawodników slalomu na podium 
Jak co roku konferencja miała charakter nieformalny, co przekładało się na możliwość bezpośredniego kontaktu z wykładowcami oraz zachęcało do zadawania pytań i dzielenia się swoimi doświadczeniami z pracy.

Prof. Piotr Rutkowski oraz prof. Andrzej Stelmach, zamykając sesję, podziękowali uczestnikom i zaprosili do ponownego udziału w przyszłym roku.

Przed Konferencją na stoku narciarskim pod Nosalem odbyły się III Otwarte Zawody Narciarskie o Puchar PTChO, w których wzięło udział około 30 członków i przyjaciół PTChO. Zwycięzcom wręczono puchary oraz pamiątkowe medale. Tytuł mistrzowski po raz trzeci obronił dr Jakub
Kenig z III Kliniki Chirurgii Ogólnej UJ CM z Krakowa, który trasę slalomu giganta przejechał najszybciej spośród wszystkich uczestników. Na kolejnych stopniach na podium wśród mężczyzn uplasowali się dr Artur Bocian z Kielc oraz dr Wojciech Wysocki z Krakowa. Wśród pań zwycięstwo odniosła studentka medycyny Katarzyna Stelmach z Krakowa, drugie miejsce zajęła także studentka medycyny Marta Stelmach z Krakowa, a trzecie miejsce dr Danuta Słota.

Trzecie Zimowe Forum Onkologiczne potwierdziło swoją pozycję w napiętym kalendarzu konferencji oraz zjazdów onkologicznych. Gorąco więc zachęcamy Państwa do udziału w przyszłorocznym spotkaniu, w styczniu 2016 roku.

\section{Dr n. med. Jerzy Władysław Mituś}

Centrum Onkologii — Instytut im. Marii Skłodowskiej-Curie Oddział w Krakowie

Katedra i Zakład Anatomii UJ CM w Kraków

e-mail:jerzy.mitus@gmail.com

\section{Dr n. med. Jakub Kenig}

III Katedra Chirurgii Ogólnej UJ CM w Krakowie 